\title{
A ESCOLA IBÉRICA DA PAZ NAS UNIVERSIDADES DE COIMBRA E ÉVORA (SÉCULO XVI)*
}

\section{The Iberian School of Peace at the Universities of Coimbra and Evora (XVI Centuries)}

\author{
Pedro Calafate**
}

\section{RESUMO}

Aborda-se aqui a consciência crítica da conquista e colonização da América nas Universidades Ibéricas do Renascimento, com especial incidência nos mestres escolásticos de Coimbra e Évora. Mostra-se como esta Escola Ibérica sustentou que o papa não tinha poder temporal ou espiritual sobre os povos americanos, quedando-lhe apenas, em matéria temporal, poder indireto sobre os assuntos temporais entre os cristãos; que em consequência não lhe assiste o direito de castigar a idolatria ou a infidelidade entre esses povos; que o imperador não é senhor do mundo, porque tal poder não se sustenta nos direitos divino, natural ou humano; que o poder laico radica imediatamente na comunidade ou povo, a título de realização da natureza social do homem e que o poder dos príncipes pagãos, em si mesmo, não é de menor nem de distinta natureza do poder dos príncipes cristãos, embora este seja mais perfeito porque a graça não contraria a natureza mas aperfeiçoa-a; que o império é uma expectativa jurídica, dependente de um pacto livre; que o poder temporal não radica nem na fé nem na caridade e que a infidelidade não é título legítimo de guerra; mostrase também a génese do princípio de intervenção humanitária em defesa dos direitos naturais dos homens, à luz da autoridade universal do orbe, tornandose a pessoa humana em sujeito de direito das gentes, bem como o princípio

* Este estudo foi elaborado no âmbito do projecto Corpus Lusitanorum de Pace, a decorrer no Centro de Filosofia da Universidade de Lisboa, sob direção de Pedro Calafate e financiado pela Fundação para a Ciência e a Tecnologia (FCT).

** Professor Catedrático da Faculdade de Letras da Universidade de Lisboa/Centro de Filosofia da Universidade de Lisboa. <pedrocalafate@hotmail.com>.

\begin{tabular}{|l|l|l|l|l|l|}
\hline Teocomunicação & Porto Alegre & v. 44 & n. 1 & p. 78-96 & jan.-abr. 2014 \\
\hline
\end{tabular}


de que na ordem internacional há um claro limite à soberania dos Estados, em nome do bem comum universal, fundado numa concepção objetiva da justiça, definida pelo jusnaturalismo escolástico.

Palavras-chave: Natureza. Justiça. Soberania. Guerra. Paz.

\section{ABSTRACT}

The critical conscience of the conquest and the colonization of America in the Iberian Universities of the Renaissance is discussed here, with special incidence in the scholastic masters of Coimbra and Evora. It is demonstrated how this Iberian School argued that the Pope didn't have temporal or spatial power over the American people, remaining for him only, in temporal matters, indirect Power over temporal affairs among Christians; that as a consequence $\mathrm{He}$ is not granted the right of punishing idolatry or infidelity among these people; that the emperor is not the lord of the world, because such Power is not supported by divine, natural or human rights; that the secular Power lies immediately in the community or people, as a way of achieving the social nature of man and that the Power of the pagan princês, in itself, is noto $f$ inferior or distinct nature from the Christian princês, although this is more perfect because Grace doesn't contradict nature but renders it more perfect; that the empire is a juridical expectation, depending on a free pact; that the temporal Power lies neither in faith nor in charity and that infidelity is not a legitimate title of war; it also shows the Genesis of the principle of humanitarian intervention in defense of the natural rights of men, in the light of the universal authority of the orb, becoming the human person a subject of people's rights, as well as the principle that in the international order there is a clear limit to the sovereignty of the States, on behalf of the universal common good, based on an objective conception of justice, definid by the scholastic natural Law theory.

Keywords: Nature. Justice. Sovereignty. War. Peace.

A publicação do Corpus Hispanorum de Pace, em Madrid, pelo CSIC, ${ }^{1}$ evidenciou a existência de relações muito ativas, nos séculos XVI e XVII, entre as universidades peninsulares de Salamanca, Coimbra e Évora, não menos intensas do que as existentes entre Salamanca, Valladolid e Alcalá, bem como a participação dos mestres das universidades portuguesas na sistematização do conceito de dignidade humana, na elaboração das bases do direito internacional moderno e, por consequência, na afirmação do conceito de comunidade internacional.

1 Corpus Hispanorum de Pace, direção de Luciano Pereña, edição do Consejo Superior de Investigaciones Científicas, 28 volumes, Madrid 1963/2012. 
Em causa estavam os princípios teológicos, filosóficos e jurídicos que deveriam orientar a convivência e relação entre povos de coordenadas culturais e civilizacionais diferentes, sobretudo os europeus, os americanos e os africanos, sem esquecer a rica experiência portuguesa no Oriente. Nesse sentido, os mestres de Coimbra e Évora fundamentaram de forma muito clara as teses sobre a soberania inicial do povo, considerando o poder político como constitutivo da natureza humana, no quadro do jusnaturalismo escolástico, evidenciando um pensamento solidário e uma unidade de Escola, em termos ainda não suficientemente estudados, pese embora o amplo conhecimento já existente, sobretudo em Espanha, dos textos de Francisco de Vitória e dos seus discípulos da Escola de Salamanca.

Como escreveu Luciano Pereña, coordenador da edição do Corpus Hispanorum de Pace:

Se na biblioteca universitária de Coimbra é possível encontrar hoje, uma das coleções mais ricas dos mestres salmantinos, também entre os fundos espanhóis, procedentes dos colégios maiores de Salamanca, podemos encontrar as mais importantes leituras de Coimbra. Esta comunicação constante de ideias contribuiu para o progresso da Escola e para a consolidação da sua unidade doutrinal. ${ }^{2}$

Por isso, importa situar na Península Ibérica o nascimento de um dos pilares da modernidade europeia, mostrando como entre nós se firmaram as bases do moderno conceito de comunidade internacional, assente no direito natural e numa concepção objetiva da justiça, sem cedência a relativismos de ocasião, ou a interesses vitais da razão de Estado, de que se alimentaria mais tarde o positivismo jurídico, bem como o afã das correntes do realismo jurídico contemporâneo.

À razão de Estado sobrepuseram sempre os mestres peninsulares a "razão da Humanidade"3 e a dignidade da pessoa humana, de que emergiam normas imperativas de Direito.

Os autores desta Escola ibérica e hispânica, espanhóis e portugueses, eram todos homens de igreja, frades e clérigos, dominicanos uns, jesuítas outros, confessores régios, quase todos catedráticos de

2 PEREÑA, Luciano. La Escuela de Salamanca y la Duda Indiana, in La Ética en la Conquista de América, CHP, v. XXV, Madrid., 1984, p. 313.

3 TRINDADE, Antônio Augusto Cançado. A Humanização do Direito Internacional, Belo Horizonte, 2006, p. VI. 
Teologia nas Universidades de Coimbra, Évora, Salamanca e Alcalá de Henares, teólogos reais no Concílio de Trento, abades de mosteiros e missionários, crentes sinceros a quem repugnava a ideia de que o Deus da paz deliberasse que os cristãos levassem a desolação e a morte àqueles que $\mathrm{O}$ não adoravam, derramando sangue dos Seus filhos, ocupando territórios alheios, expropriando os bens das comunidades indígenas e esmagando as suas soberanias, ainda que embrionárias, em territórios que nunca haviam pertencido aos cristãos, mediante práticas de crueldade a que se não tinham atrevido ainda os piores tiranos.

Tais procedimentos eram por eles encarados como antievangélicos e vincadamente contrários ao direito divino, natural e humano, afrontando a paternidade divina, à luz da qual todos os homens foram criados livres por Deus, à Sua imagem e semelhança. Assim se fundava, na mais nobre raiz, a igualdade e irmandade natural entre os homens, no quadro do antigo preceito paulino de que "não há diferença entre judeu e grego" (Rm 10:12), alargado agora à pluralidade dos homens e dos povos recém-descobertos.

Em causa estavam, como dissemos, os princípios teológicos, filosóficos e jurídicos que deveriam orientar a convivência e relação entre povos de coordenadas culturais e civilizacionais diferentes, sobretudo os europeus, os americanos e os africanos, sem esquecer a rica experiência portuguesa no Oriente. Nesse sentido, os mestres de Salamanca, Coimbra e Évora fundamentaram, em termos muito claros, as teses sobre a soberania inicial do povo, considerando o poder político como constitutivo da natureza humana, no quadro do jusnaturalismo escolástico.

Assim se fundamentava a necessidade de respeitar a legitimidade das soberanias indígenas, mostrando que o poder político entre os príncipes pagãos, em si mesmo, não era de menor nem de distinta natureza do que o poder dos príncipes cristãos, e que as considerações teóricas acerca da fundamentação do poder civil, na razão natural e na natureza social do homem, eram válidas para o conjunto da humanidade, independentemente das diversidades culturais e religiosas. Neste contexto, a legitimidade do poder civil dos cristãos sobre os infiéis deveria ser considerada no mesmo plano da legitimidade do poder civil dos infiéis sobre os cristãos.

O poder civil era inerente às comunidades humanas, não dependia da fé nem da caridade, assim como não podia considerar-se, à partida, dependente de uma ordem jurídica de natureza imperial, porque, como 
dizia Martín de Azpilcueta, em Coimbra, em 1548, “a lei imperial não suprime as providências naturais". ${ }^{4}$ Nesse contexto, importava fundamentar tanto a tese de que o papa não possuía autoridade temporal ou espiritual sobre os povos estranhos ao mundo cristão (possuindo apenas poder espiritual entre os cristãos, bem como poder indireto sobre os assuntos temporais, entre os cristãos, em ordem ao fim espiritual), como a de que os imperadores romano-germanos ou os reis peninsulares não podiam considerar-se senhores do mundo, devendo entender-se tal título apenas como hipérbole, ou, na pior das hipóteses, como arrogância.

Nem o papa poderia considerar-se dominus orbis in temporalibus et spiritualibus, nem a autoridade imperial se estendia a todos os povos do mundo, tanto do ponto de vista do direito divino, como do direito natural e do direito humano, situando-se no contexto deste último a questão fundamental da guerra justa e, consequentemente, da escravatura, que tinha no direito bélico o seu principal título legítimo, acrescido pela venda voluntária em necessidade extrema, trocando o valor da liberdade pelo maior valor da vida, ou pela condenação por crimes graves à luz do direito interno dos Estados.

O império universal seria considerado ou como um desígnio humana e moralmente impossível ou como uma expectativa jurídica com opção preferente, no sentido em que, tendo em conta as doações papais, apenas os reis de Portugal e Espanha poderiam, entre todos os príncipes cristãos a que se estendia o poder indireto do papa em assuntos temporais, mover guerra justa nas Índias Ocidentais e Orientais, respetivamente, sem interferência dos demais príncipes cristãos, configurando uma opção preferencial do papa; por outro lado, em virtude das mesmas doações papais, em caso de pacto translativo do poder, apenas os reis peninsulares poderiam receber, entre os demais príncipes cristãos, o poder civil que fosse transferido ou concedido livremente pelos povos das duas Índias aos príncipes cristãos, em virtude da mesma opção preferencial do sumo pontífice.

Por outras palavras, para os autores da Escola Ibérica da Paz, o papa não podia, fora do redil da Igreja, conceder o direito de conquistar primeiro para evangelizar depois, não podia desrespeitar o legítimo direito ao domínio de jurisdição e propriedade dos povos indígenas da América, porque Cristo não lhe concedera a espada temporal nem, por

\footnotetext{
4 AZPILCUETA, Martín de. Relectio C. nouit de iudiciis, Coinimbricae, 1548, p. 51-53, tradução de A. Guimarães Pinto (no prelo).
} 
consequência, o Seu poder temporal direto; não podia conceder aos reis hispânicos, o direito de castigar a idolatria e as demais ofensas a Deus cometidas por esses povos, porque não tinha poder espiritual sobre eles, pois Cristo não concedera a Pedro e aos seus sucessores poder espiritual sobre os povos do mundo inteiro, mas apenas sobre os já batizados; não podia reivindicar para si o direito de recorrer ao braço armado dos príncipes cristãos para castigar crimes contra a natureza, como o incesto e a bigamia, porque entre os povos cristãos tais práticas também eram conhecidas e os franceses não podiam, por isso, castigar ou atacar os italianos em punição de tais crimes, pois isso subverteria totalmente a ordem internacional. Em suma, fora das fronteiras da Cristandade, o papa apenas podia conceder o que Cristo ordenou aos Apóstolos: "Ide e pregai o Evangelho a toda a criatura" (Mc 16:15), quer dizer, o direito e dever de pregar em todo o mundo, pacificamente, bem como os meios temporais necessários a tal fim espiritual, que, neste caso, entravam na alçada do seu poder indireto sobre as coisas temporais. Então, em virtude da autoridade apostólica, o papa podia proibir aos demais príncipes cristãos o direito ao comércio nas terras e mares do Novo Mundo e das Índias Orientais, na medida em que tal atividade, sendo temporal, tinha em vista um fim espiritual e era um meio indispensável à realização de tal fim, sendo certo que quem dá a obrigação de realizar uma obra, dá também os meios necessários à sua concretização.

Porém, era importante levar em conta uma prevenção essencial: se este direito à pregação universal, concedido diretamente por Cristo à Sua Igreja, fosse obstruído pela força, poderia o papa pedir o auxílio do braço armado dos príncipes cristãos, com o fim de remover a força com a força. Todavia, embora tal fosse lícito, poderia não ser conveniente, sendo previsível que criasse mais obstáculos futuros do que benefícios presentes, pelo ódio que em regra nasce do emprego da força, ainda que legítima.

Chamamos a propósito a atenção para o caso de Frei António de São Domingos, professor da Universidade de Coimbra entre 1573 e 1593, cuja obra permanece inédita, e que, tanto quanto nos é dado saber, foi dos primeiros que, mesmo contra o fundador da Escola, Francisco de Vitória e os seus discípulos de Salamanca, pôs em causa este título legítimo de guerra, com um argumento digno de nota.

De fato, este direito concedido por Cristo aos Apóstolos não era um direito natural, no sentido em que não radicava em absoluto na razão natural comum a todos os homens. Francisco Suárez, aliás, explicita-o 
bem, em texto que aqui pela primeira vez se traduz, ao considerar que "este direito não é completamente natural, de certa forma é sobrenatural, e basta que assumamos a revelação e a doutrina que acolhemos, para podermos justificar de maneira suficiente o nosso direito, demonstrando também que é consentâneo à razão, assim como necessário à salvação da alma. Isso nenhuma outra seita nos pode demonstrar e é algo que para nós é evidente". 5

Ora, Frei António de São Domingos põe diretamente em causa esse direito da igreja, também defendido por Suárez em Coimbra, porque não era possível provar aos gentios, em termos estritamente racionais, que possuíamos tal direito, e como era com base na razão natural que primeiro comunicávamos com esses povos, não podíamos mover-lhes guerra com base em argumentos que, sendo «consoantes à razão», como dizia Suárez, não eram completamente naturais. Ou seja, os gentios tinham direito a não se deixarem convencer pelos nossos argumentos, estabelecendo-se assim o direito da guerra em plano estritamente racional e retirando-lhe, por isso, o plano confessional. Diz o frade dominicano, nas suas lições sobre o direito da guerra:

$<$ Diz-se que $>$ se os bárbaros embaraçam os pregadores do Evangelho proibindo-os de pregarem entre eles, esta é uma justa causa para fazer-se-lhes guerra, pois podemos, através da força e das armas, compeli-los a que permitam que livremente se pregue o Evangelho. Victória e os restantes defendem esta opinião e provam isto porque Cristo nos deu o poder de pregar o Evangelho: $M t$ 28. 19.: 'Ide e ensinai todas as gentes' etc.; e Mc 16. 15.: 'Ide por todo o mundo, pregai o Evangelho a toda a criatura' etc. Logo, se alguém quiser privar-nos do nosso direito, temos motivo de justa guerra contra esses, respeitando-se aquilo que deve respeitar-se. E isto se confirma porque aqui se trata do proveito deles mesmos; logo, podemos ir empós disto, mesmo contra a vontade deles. E provase, em último lugar, porque de outro modo eles já ficariam sem remédio.

Todavia, e salva melhor opinião, esta causa não parece suficientemente justa, e prova-se porque o Senhor quer que o Evangelho seja pregado com mansidão, e não pela força das armas, como provámos atrás. Em segundo lugar, porque eles teriam

\footnotetext{
SUÁREZ, Francisco. De mediis quibus infideles possint licite ab hominibus ad fidem adducit, Roma, Universidade Gregoriana, ms. 452, ff. 365-370, quaestio $4^{\mathrm{a}}$, tradução deste excerto de Miguel Sena Monteiro.
} 
em relação a nós um justo motivo de escândalo, porquanto não podemos provar-lhes que Cristo pôde conceder este direito. ${ }^{6}$

A limitação do poder papal, conduzida por jesuítas e dominicanos das Universidades de Salamanca, Alcalá, Évora e Coimbra, exerciase em plano de vincada adversidade, pois contra eles se levantava a tradição decretalista da teocracia. Era o caso, muito citado pelos autores desta Escola, do Bispo de Silves, do século XIV, Álvaro Pais, natural da Galiza, que apoiado no cardeal hostiense, Henrique Segúsio, ${ }^{7}$ sustentava a tese de que o papa era dominus orbis no temporal e no espiritual, na qual viria a basear-se uma ética colonial de conquista e subjugação dos pagãos e gentios da América.

Álvaro Pais, tal como a maioria dos teocratas dos séculos XIV e $\mathrm{XV}$, tinham a seu favor a interpretação mais literal $^{8}$ da Extravagante do papa Bonifácio VIII, escrita em 1302, intitulada Unam sanctam. Nos termos desta Extravagante, podia ler-se que "quem nega que em poder de Pedro se encontra a espada temporal, não toma em atenção as palavras do Senhor, quando disse: 'Embainha a espada"' e mais adiante, sublinhava Bonifácio VIII que "Em poder da Igreja encontramse tanto a espada espiritual como a temporal". Então, para Álvaro Pais, "o papa tem jurisdição universal em todo o mundo, não só nas coisas espirituais, mas também nas temporais [...] porque assim como há um só Cristo, sacerdote e rei, senhor de todas as coisas, assim também há um só vigário-geral seu na terra e em tudo [...]. O papa é vigário não dum puro homem mas de Deus [...]; logo, também pertencem ao papa a terra e a sua plenitude < porque $>$ Cristo concedeu os direitos dos dois poderes a S. Pedro". ${ }^{9}$ A enquadrar esta plenitude do poder papal estava a tese de que o poder político provém de Deus através do papa, pelo que o poder do imperador e dos demais príncipes seculares era-lhes concedido

6 SÃO DOMINGOS, António de de Bello. ms 5.552 da Biblioteca Nacional de Portugal, fol. $67 v^{\circ}-68$, tradução de A. Guimarães Pinto (no prelo).

7 SEGUSIO, Enricus de (Hostiensis). In tertium Decretalium librum commentaria, cap. 8, n. $14-16$.

8 Refiro a interpretação mais literal, pois os adversários da teocracia interpretavam a mesma Extravagante de maneira diferente. Sirva de exemplo a belíssima Relectio, pronunciada por Martin de Azpilcueta em 1548, perante a Assembleia da Universidade de Coimbra, no final do ano letivo, em que refere que o papa Bonifácio VIII queria apenas dizer que «o poder laico deve submeter-se ao espiritual quando o interesse das coisas sobrenaturais assim o exigir», in Relectio c. nouit de iudiciis, Coimbra, 1548, anotação 3, 54.

9 PAIS, Álvaro. De Status et Planctu Ecclesiae, vol. I, INIC, Lisboa, 1983, p. 345-347, tradução de Miguel Pinto de Meneses. 
diretamente pelo pontífice romano e não pelo povo, ao contrário do que defendiam Vitória, Suárez, Molina e os demais autores da Escola Peninsular da Paz.

Já quanto a Henrique Segúsio, cardeal hostiense, em quem o autor galego se apoiava, sustentava que, com a vinda de Cristo, o poder civil dos infiéis, gentios e pagãos foi-lhes retirado e transferido para o seu vigário e cabeça da Igreja, ${ }^{10}$ razão por que o domínio de jurisdição e propriedade entre os infiéis era de todo ilegítimo.

Sublinhe-se, no entanto, que o ponto culminante destas concepções teocráticas, no final da idade média, foi a obra de Egídio Romano, intitulada De ecclesiastica sive de summi pontificis potestate, ${ }^{11}$ escrita no início do século XIV, na qual defende que foi o poder espiritual que instituiu o poder temporal, razão por que só os reinos que reconhecem o papa como instituidor são legítimos.

Para Egídio, a verdadeira justiça, fundamento do poder político, só existe naquela república cujo fundador e governador é Cristo; então, nada está sob o governo de Cristo se não estiver sob o sumo pontífice que é vigário de Cristo. Logo, os povos que não reconhecem a autoridade do sumo pontífice não são legítimos possuidores dos seus bens nem os seus reis legítimos governantes. Só pelo batismo o homem pode possuir legítimo domínio e por isso os infiéis não são legítimos possuidores.

Foi com base em concepções desta natureza - difundidas, também, no período medieval, por Tiago de Viterbo, Henrique de Cremona e Agostinho Triunfo -, que se fundou uma linha de atuação e expansão imperial cujo melhor exemplo é seguramente o Requerimiento, redigido pelo Doutor Palácios Rúbios, no qual se formalizaram as conclusões da Junta de Valladolid (1513), mandada reunir pelo rei de Espanha, Fernando de Aragão, e que constituiu, para o caso Espanhol, «o manifesto da Coroa que os conquistadores deveriam ler aos índios antes da abertura das hostilidades, vindo a transformar-se na fórmula final da nova ideia de justiça colonial», ${ }^{12}$ levada à prática na conquista do México e do Peru.

Entre os termos do Requerimiento constava a obrigação dos povos americanos reconhecerem o "senhorio universal do papa", ou seja, nas palavras de L. Pereña: "O Requerimento proclamava o senhorio

\footnotetext{
${ }^{10}$ SEGÚSIO, Enricus de (Hostiensis). Op. cit., cap. 8, n. 14-16.

${ }^{11}$ Existe desta obra uma excelente tradução em língua portuguesa: Egídio Romano, Sobre o Poder Eclesiástico, trad. L.A. De Boni, Petrópolis, 1989.

12 PEREÑA, Luciano. La Idea de Justicia en la Conquista de América, Madrid, 1992, p. 35.
} 
universal do papa, a doação pontifícia das Índias aos reis de Espanha e o mandato que lhes foi imposto para evangelizar e predicar a fé cristã aos habitantes das terras descobertas e a descobrir. Em virtude destes títulos - senhorio universal do papa, delegação política, única e exclusiva, em favor da monarquia espanhola e direito a evangelizar e predicar a fé católica - o imperador deveria ser reconhecido como soberano sobre os reis e caciques das Índias". ${ }^{13}$

Até aqui, o poder e autoridade do papa. Quanto ao poder e autoridade do imperador ou dos imperadores romano-germanos, era também fortemente limitado de modo corajoso e desassombrado, com base nas teses sobre a origem democrática do poder civil ou temporal, como na altura se designava.

Veja-se o texto de Martín de Azpilcueta, na sua Relectio de 1548, lida perante a assembleia magna da Universidade de Coimbra:

Quando os povos não têm a luz e o apoio de um imperador, é mister que sejam para si a sua própria luz, e quem não tem guia e chefe, é o seu próprio chefe e guia. E assim, embora algum povo não tenha chefe nem rei mediante providência humana, contudo recebeu da natureza naturante, que é Deus, o poder de se dirigir, governar e iluminar [...], e se se encontrassem alguns homens associados em comunidade, estes teriam do próprio Deus, de modo imediato, o poder de se governarem a si mesmos e de fazerem as coisas sem as quais não poderiam viver em sociedade [...], pois a lei imperial não pode suprimir as providências naturais. Não vai em sentido contrário o fato de que muitos povos parecem carecer completamente de jurisdição. Na verdade, não carecem completamente de jurisdição mas do seu uso. ${ }^{14}$

Do ponto de vista da sua natureza, o poder civil não foi concedido direta e imediatamente por Deus aos príncipes, mas sim pelos homens associados em comunidade. Deus é a origem do poder enquanto autor da natureza social do homem, pois quem dá a essência de uma coisa dá também aquilo que dela se segue, e como o exercício do poder civil se segue necessariamente à constituição e conservação da sociedade, Deus é, nesse sentido, a Causa Primeira e Universal do poder civil em todos os reinos e principados da terra, mas não é a sua causa próxima!

\footnotetext{
${ }^{13}$ Ibidem. p. 35 e 36

${ }^{14}$ AZPILCUETA, Martín de. Relectio C. nouit de iudiciis, Coinimbricae, 1548, p. 74. Tradução do latim de António Guimarães Pinto (no prelo)
} 
Quem transmite ou concede diretamente o poder civil aos príncipes é o povo, no sentido de comunidade. Logo, o poder civil é constitutivo de todas as comunidades humanas espalhadas pelo orbe, radica na sociabilidade natural que Deus deu a todos os homens e, portanto, na razão natural. Nesse contexto, a democracia era a mais natural forma de governo, no sentido em que não precisava de ser positivamente instituída, podendo embora os povos optar por outras formas legítimas de governo, como a monarquia ou a aristocracia, bem como por formas mistas que delas derivassem.

Então, nenhum rei, príncipe ou imperador tem o direito de se considerar empossado de autoridade universal sobre os homens, invocando o direito divino, natural e humano.

Não pode ser invocado o direito divino, porque em nenhum lugar se lê que Deus tenha dado tal poder universal a quem quer que fosse; não o direito natural, porque o poder civil radica, a igual título, na natureza das várias comunidades que se constituíram sobre a terra; não o direito humano, porque nunca ninguém conquistou o mundo inteiro em guerra justa, nem foi livre e democraticamente eleito pelos povos da terra, nem sequer pela sua maior parte.

Valham para tanto as palavras de António Vieira, proferidas em São Paulo, em 1694: “(...) importa igualmente para a soberania e liberdade tanto a coroa de penas como a de ouro, e tanto o arco como o cetro", ${ }^{15}$ embora - dado não estarmos em contexto multiculturalista em sentido atual -, o poder dos príncipes cristãos fosse mais perfeito, porque a graça, não contrariando a natureza, aperfeiçoa-a.

António Vieira era, ao contrário de Francisco Suárez, partidário convicto da monarquia universal, mas não deixou por isso de a sujeitar aos títulos legítimos de aquisição do poder, fazendo-a depender de uma eleição universal por parte dos reis e príncipes da terra, que receberam dos povos o direito da paz e da guerra, porquanto a monarquia universal era, afinal, a celebração da paz na terra, fundada na justiça.

Vejam-se de novo as palavras de Martín de Azpilcueta na sua Relectio de 1548 em Coimbra:

Não foi estabelecido por Cristo algum poder temporal laico que abarcasse todas as coisas [...]. Em nenhuma ocasião Deus ordenou regularmente que se obedecesse a um só, a muitos, a estes ou

\footnotetext{
${ }^{15}$ ANTÓNIO, Vieira. Votos sobre as Dúvidas dos Moradores de S. Paulo, 1694.
} 
àqueles, relativamente ao poder laico [...]. Nada especialmente foi estipulado relativamente à sua criação ou entrega do mesmo a alguém, pelo menos no princípio da criação sua e do género humano [...]. Uma coisa é o poder régio ser imediatamente criado por Deus, e outra ser transmitido a este ou àquele homem. Não prova em sentido contrário a seguinte passagem 'Por mim reinam os reis' $(\operatorname{Pr} 8,15)$ e aqueloutra 'Todo o poder vem de Deus' $(R m 13,1)$, porquanto, no máximo, apenas provam que o poder régio foi criado imediatamente por Deus, não porém que foi imediatamente dado por Ele a este ou àquele homem. ${ }^{16}$

Não podem por isso os reis de Espanha ou de Portugal invocar a autoridade do papa para ocuparem pela força o Novo Mundo, porque, como vimos, o papa não pode dar o que não é dele; nem podem invocar autoridade própria, pois também a não tinham, em função do fundamento jusnaturalista do poder civil, razão por que, como diz Vitória, a conquista do México e do Peru foi ética e juridicamente ilegítima, destruindo, ponto por ponto, as várias alíneas do Requerimiento.

Em qualquer lugar da terra onde existam soberanias indígenas legitimamente constituídas, com base no direito natural promulgado por Deus para todos os homens em condições de igualdade e universalidade, só mediante consentimento livre e responsável dos homens ou em resultado de guerra justa poderia admitir-se a translatio imperii. Senão, não!

Diz portanto Martín de Azpilcueta:

Erra a opinião corrente [...], na medida em que pensa que por Direito Divino é necessário que exista uma única soberania laica sobre o mundo inteiro, da mesma maneira que existe uma única soberania eclesiástica. Porque em primeiro lugar tal não se prova por nenhum direito divino sobrenaturalmente dado ou revelado [...]. Em segundo lugar tal não pode concluir-se por nenhuma razão natural [...]. Igualmente erra um grande número que pensa que o imperador dos Romanos é senhor e rei do mundo e da terra porque o imperador Antonino dissera: "Eu sou senhor do mundo" [...], pois não é de presumir que o imperador Antonino de tal modo carecesse de senso que com aquelas palavras significasse a sua convicção de que era senhor da terra inteira, que, nem mesmo

${ }^{16}$ AZPILCUETA, Martín de. Op. cit., p. 75 e 87, tradução de António Guimarães Pinto (no prelo). 
dividida ao meio, jamais se submeteu nem a ele nem a nenhum dos seus predecessores.

Conquanto que seja verdade que se todas as cidades da terra e os governantes delas, aos quais interessasse, acordassem em que um só fosse eleito governante, rei ou imperador de todos, seria verdadeiro governante, rei ou imperador aquele a quem a maior parte escolhesse [...], porque é da mesma natureza e espécie o poder com que os reis reinam e o poder com que a si mesmas se governam as cidades livres. ${ }^{17}$

Por sua vez, a condição da justiça da guerra fora também drasticamente limitada aos casos de agressão ou ofensa grave, e não tendo os povos da América agredido os cristãos antes destes desembarcarem nas suas terras, e não nos tendo ofendido com gravidade na mesma circunstância, dificilmente poderia invocar-se esse título, pois, mesmo nos casos em que tivéssemos sido agredidos em território americano, era razoável supor que tal ficara a dever-se a uma reação legítima, em função do medo que o aparato bélico dos cristãos motivava nesses ou quaisquer outros povos, dando-se então uma guerra justa por ambas as partes: uma por ter o direito do seu lado, outra por ignorância insuperável. É o que sustenta o professor da Universidade de Évora, Pedro Simões, no seu manuscrito latino sobre o direito da guerra:

Os Hispanos que são proibidos pelos bárbaros $<$ de se dedicarem ao comércio legítimo> não podem mover imediatamente uma guerra ofensiva, porque os bárbaros, ao verem homens estrangeiros armados e mais poderosos, com razão podem ter medo, e em consequência no princípio poderiam sem culpa proibir os hispanos de tal comércio. Portanto, os hispanos deverão agir de acordo com esta norma: em primeiro lugar impeçam a revolta mediante argumentos, mostrem que não vieram com ânimo de prejudicar os índios e mostrem ainda que os bens supraditos são de todos, conforme o Direito das Gentes. Contra si próprios cometeriam injúria os bárbaros, negando-se a pactuar e tomando as armas contra os hispanos. Poderiam então estes defender-se e fazer tudo aquilo que julgarem necessário para a sua defesa. Mas, depois de alcançada a vitória, não os poderão matar ou apoderar-se dos seus bens, porque tal guerra é apenas defensiva, e os bárbaros são indefensos e têm medo com razão. ${ }^{18}$

${ }^{17}$ Ibidem, p. 98, tradução de A. Guimarães Pinto (no prelo).

18 SIMÕES, Pedro. Annotationes in materiam de bello, 1575, ms. da BNP 3.858, quaestio I, fol. $304 v^{\circ}$. Transcrição do manuscrito latino de Joana Serafim, tradução do latim de Marina Castanho e Ana Maria Tarrío (no prelo). 
Mesmo quando se invocava o direito natural que os cristãos tinham para exercerem atividade comercial nos territórios dos povos americanos, teria que levar-se em conta a condição essencial desse direito: não poderia ser exercido em manifesto prejuízo dos nacionais e deveria ser desenvolvido na base da amizade natural entre os homens, aqui padronizada pelo ius amicitiae e pelo ius communicationis, por não ser lobo o homem para o homem.

Mas havia uma linha vermelha, como em todo o quadro jurídico, que definia um limite inultrapassável: não eram toleráveis crimes contra a humanidade, aqui designados por crimes contra o "género humano", que no caso americano se verificavam sobretudo em duas situações: sacrifícios humanos aos ídolos e morte de inocentes para serem comidos.

Com efeito, qualquer povo, cristão ou gentio, mesmo que não nos ofendesse ou agredisse diretamente, nas nossas terras ou nas nossas pessoas, cometia uma agressão insuportável contra nós se violasse o direito à vida e à integridade física dos inocentes, fossem quem fossem, estivessem onde estivessem e tivessem o soberano que tivessem, pois então não seria já soberano, mas tirano, e à luz do direito de resistência ativa, ${ }^{19}$ podia e devia ser destituído.

Nesses casos, o sangue dos inocentes era um grito universal de socorro que deveria ser ouvido e impedido pela guerra, se não existissem mais alternativas, em nome da dignidade do género humano e com a legitimidade conferida pela autoridade universal do orbe, o totus orbis vitoriano, ${ }^{20}$ que transformava cada ser humano em sujeito de direito das gentes, semente do direito internacional.

Esse era, diziam os mestres peninsulares desta Escola da Paz, o único crime contra a lei natural que deveria ser punido pelos cristãos por meio da guerra no Novo Mundo ou em qualquer outra parte da terra, em referência direta ao sacrifício de seres humanos aos ídolos ou à morte de inocentes para serem comidos em práticas de canibalismo. Estas práticas agrediam o género humano como um todo e, como tal, tínhamos o dever

${ }_{19}$ Sobre este tema, veja-se Pedro Calafate, Da Origem Popular do Poder ao Direito de Resistência, Lisboa: Esfera do Caos, 2012.

${ }^{20}$ Diz Francisco de Vitória na sua Relectio sobre o poder civil: "O orbe inteiro, que de certo modo constitui uma única República, tem poder para promulgar leis justas e convenientes para todos, como são as leis do Direito das Gentes. Segue-se que pecam mortalmente os que violarem o Direito das Gentes, seja na paz seja na guerra [...]. Não é lícito a um reino particular não querer ater-se ao direito das gentes, pois foi promulgado pela autoridade do orbe inteiro." Relectio de potestate civili, Salmanticae, 1528, 21, tradução deste excerto de Miguel Sena Monteiro. 
de as impedir, mas tendo o cuidado de sublinhar que a vitória obtida nesta guerra não nos daria o direito de ocupar os territórios destes povos, reduzindo-os à escravatura.

Diz então Luis de Molina, nas lições de Évora, publicadas em Cuenca, em 1593:

É lícito impedir que os infiéis e quaisquer outros homens cometam pecados que suponham injúria aos inocentes. E se não quiserem abster-se destes crimes, será lícito declarar-lhes guerra por esta causa, nos termos do direito bélico, sem necessidade de autorização do papa. É o caso do sacrifício de inocentes, ou o dar-lhes morte para se alimentarem das suas carnes, ou o assassínio e opressão através de leis tirânicas.

Devemos impedi-lo de qualquer modo que seja, pois qualquer homem pode, por Direito Natural, e sobretudo os príncipes, defender os inocentes da tirania e da opressão. [...]. E não importa que os mesmos bárbaros súbditos desejem estes costumes e sacrifícios, não querendo que os estrangeiros façam guerra por esta causa, pois qualquer um pode livrar outro da morte, mesmo contra a sua vontade, incluindo o que procura matar-se a si mesmo, como é notório.

Observe-se, não obstante, que esta guerra não se declara para recuperar algo nosso, nem para vingar injúrias próprias, mas para defender os inocentes enquanto pertencem ao género humano, não sendo lícito a quem declara a guerra apoderar-se dos bens do

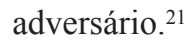

Pela sua importância, ineditismo e significado, transcrevemos mais um texto sobre este tema, desta feita do manuscrito latino sobre a guerra, de Fernando Pérez, professor da Universidade de Évora entre os anos de 1559 e 1572, tendo chegado a ocupar o cargo de Vice-Reitor daquela Universidade:

É contra o Direito Natural matar inocentes, quer indígenas quer estrangeiros, ou para comê-los ou para sacrificá-los aos ídolos. Pelo que, se se objetar que todos estes bárbaros consentem voluntária e livremente naquele ritual, e não se pratica injustiça contra quem anui, responde-se [...] que eles não têm por si direito para poderem

${ }^{21}$ MOLINA, Luis de. De iustitia et iure, Cuencae, 1593, tomo I, liv. III, disp. C, tradução deste excerto de Pedro Calafate. 
entregar-se a si ou os seus à morte. Em segundo lugar, responde-se que eles praticam uma gravíssima injustiça, pelo que podem ser vencidos por nós, que fazemos parte do género humano, na sua condição de injustíssimos $\left[v^{\circ}\right]$ agressores do género humano. ${ }^{22}$

O mesmo raciocínio era patente em se tratando não de indivíduos mas de Repúblicas, Comunidades ou Estados. A autoridade universal do orbe não se resumia a um direito interestados, mas a um plano ético que estava claramente acima deles, donde dever concluir-se que a ordem jurídica internacional não procedia apenas do Estado, não estava fechada nas suas leis particulares, não derivava do movimento espontâneo das instituições e não admitia uma plenitude sem limites da soberania dos Estados e dos seus interesses particulares. Contra o que hoje poderia chamar-se individualismo internacional, decorrente das concepções hobbesianas, postulava, em pleno século XVI, o professor Martín de Ledesma, na sua cátedra de Coimbra:

Sendo uma república parte de todo o orbe e, maximamente, sendo uma província dos cristãos parte de toda a República cristã, se a guerra for útil a uma república ou reino em detrimento e com prejuízo de todo o orbe ou da Cristandade, eu considero que por isso mesmo ela é injusta. ${ }^{23}$

Por outro lado, em caso de intervenção humanitária em defesa dos direitos dos inocentes, entendia-se também que a noção de proporcionalidade dos meios deveria ser respeitada, por não ser aceitável combater o terror com o terror, causando maiores danos do que os que se pretendiam evitar, de modo a impedir o que hoje chamaríamos "terrorismo de Estado".

Na mesma categoria de crimes contra o género humano, estavam as ações dos soldados na guerra injusta, mesmo quando em obediência estrita a ordens superiores. Ou seja, a invocação de ordens superiores não escusava um soldado por atos não cobertos pelo direito bélico, cabendolhe, em caso de dúvida manifesta sobre a justiça da guerra, examinar as suas causas. Então, caso concluísse tratar-se de guerra injusta, o soldado,

${ }^{22}$ PÉREZ, Fernando. De bello, ms. 3.299 da Biblioteca Nacional de Portugal, Conimbricae, 1588, fol. 228. Transcrição paleográfica de Filipa Roldão, tradução do latim de António Guimarães Pinto (no prelo)

${ }^{23}$ LEDESMA, Martín de. Secvnda Qvartae, Conimbricae, 1560, fol 316r-v, tradução deste excerto de Leonel Ribeiro dos Santos. 
mesmo o de mais baixa condição, era obrigado, no foro externo e no foro interno da consciência, a recusar-se a combater ou a acompanhar o seu rei, porque um soldado não tinha o estatuto de um carrasco a quem cumpria obedecer, sem prévia análise pessoal em caso de dúvida, à sentença de um juiz legítimo.

$\mathrm{O}$ alcance deste preceito, exigindo de cada soldado a desobediência aos superiores por imperativos de consciência, revela-se como uma das mais vincadas contribuições da Escola Peninsular da Paz para a afirmação da dignidade da pessoa humana, mesmo nas situações mais extremas e difíceis da guerra e da rígida subordinação hierárquica. Não havia, pois, escusa para a barbárie, tida por ofensa à dignidade do próximo. Nestes casos, valia a afirmação do apóstolo Pedro: "Importa mais obedecer a Deus do que aos homens" (At 5:29).

É o que ensinava Fernando Pérez em Évora:

Podem ser tão claros os indícios da injustiça de uma guerra que, de acordo com a usança humana, se segue que deve presumir-se a certeza da injustiça da guerra, e que no foro exterior os soldados, mesmo os de mais baixa graduação, não devem ser escusados, como tão-pouco no foro íntimo ou sacramental, se a ignorância da injustiça, depois de conhecida toda a situação, tiver sido totalmente grosseira. $^{24}$

Tampouco poderia invocar-se o argumento da conquista para a civilização, por serem os europeus mais sábios que os chamados bárbaros da América, pois essa qualificação de rudeza ou incultura não era absolutamente verdadeira, houvesse em vista as civilizações existentes no México e no Peru, como sublinhava o professor da Universidade do México, Alonzo de Veracruz, em $1554 ;{ }^{25}$ e quando o fosse, não era aceitável dizer-se que a rudeza ou incultura impediam o

\footnotetext{
${ }^{24}$ Op. cit., f. 236.

${ }^{25}$ Escreve Alonzo de Veracruz: "Os habitantes deste Novo Mundo não só não são crianças ou amentes, mas são, a seu modo, bem dotados, e ao menos alguns deles, a seu modo, muito bem dotados. Isto é evidente: antes da chegada dos espanhóis, como acabamos de o constatar com os nossos olhos, havia entre eles autoridades, governos e ordenanças sumamente apropriados, e tinham comunidade política e regime não só monárquico, mas também aristocrático; e entre eles existiam leis e castigavam os malfeitores, assim como premiavam os beneméritos da república [...]. Segue-se que aqueles, quem quer que sejam, que os consideram indignos do domínio ou do reino ou de outras esferas em que eram verdadeiros donos, alegam um título injusto." (VERACRUZ, Alonzo de. De Iusto bello contra Indos, (1553-1554?), Quaestio V, Septima Conclusio, tradução deste excerto de Pedro Calafate).
} 
exercício do domínio de jurisdição e propriedade, pois era direito trazido à natureza comum dos seres humanos através da escrita de Deus, como tão eloquentemente mostrou o já citado Martinho de Ledesma, na sua obra Secunda Quartae, publicada em Coimbra em 1560:

Ainda que algumas nações sejam rudes e imbecis, não é lícito fazerlhes guerra ou ocupar as suas terras. A razão está em que aquela servidão [que resulta de, por serem limitadas, só poderem executar atividades subordinadas] não lhes tira a liberdade, como acontece àqueles que se vendem, ou são cativos de guerra, ou são reduzidos à servidão racionalmente segundo as leis. Mas contra isto poderá invocar-se aquilo que Aristóteles diz na Política I, cap. 3, a saber, que, tal como podemos vender os animais, assim podemos fazer guerra contra aqueles homens que nasceram para obedecer. Mas, a esta objeção, eu respondo que isso que Aristóteles diz deve ser entendido somente a respeito daqueles que vivem à maneira das feras, não respeitando nenhuns pactos entre os povos. [...] Esses tais podem ser submetidos pela força e coagidos a obedecer a alguma ordem, não, porém, todos os homens que são rudes e agrestes. ${ }^{26}$

Era pois necessário enfrentar a tese aristotélica da escravatura natural. Ao contrário do que dissera Aristóteles no livro da Política, não havia escravatura natural, dado que todos os homens foram criados livres por Deus; nem os bárbaros podiam ser combatidos em virtude da sua rudeza, como decorria dos textos do Estagirita.

O momento mais alto da recusa deste argumento, delineado por um jesuíta de formação escolástica e, portanto, aristotélica, foi escrito por José de Acosta, em texto que, pela sua valia, aqui reproduzimos:

Aquilo que se alega, com base em Aristóteles, sobre a guerra justa contra os bárbaros que se recusam a aceitar o domínio, é algo bem difícil de entender, e desperta não pequenas suspeitas de que essa tese não resulte de razões filosóficas mas sim da opinião popular [...]. E se Alexandre Magno (como dizem alguns, atraído pela ambição do poder) quis levar as bandeiras macedónias por todo o universo, não devemos preocupar-nos demasiado com o que Aristóteles escreveu mais por motivos de adulação do que de filosofia. ${ }^{27}$

${ }^{26}$ LEDESMA, Martín de, Secvnda Qvartae, Conimbricae, 1560, fol. 225v, tradução deste excerto por Leonel Ribeiro dos Santos.

${ }^{27}$ Acosta, José de. De Procuranda Indorum Salute, Salmanticae, 1528, V, 1-2, tradução deste excerto de Pedro Calafate. 
Neste âmbito das diferenças de desenvolvimento cultural, na marcha unilinear do tempo e do conhecimento da verdade, apenas se deparava a estes professores e missionários, como hipótese viável, a educação e a elevação do vulgo à altura do homem, que naquela época era matrizada pelo humanismo cristão.

Então, as naus que saíam da Hispânia, em tempos próximos e rotas distintas, deviam levar Cristo ao coração de todos os homens, convidando-os a que ouvissem a sua voz, como se lia em Mateus (Mt 28, 19:20), porém, acima de tudo, importava respeitar a vontade do Divino Legislador: "Farás o que é justo de maneira justa" (Dt 16:20), não sendo legítimo fazer o mal para obter o bem. E caso nos não quisessem receber, não havia motivo para os subjugar, pois Cristo ensinara aos Apóstolos que "Se não vos quiserem receber, ao sair de suas casas, sacudi o pó dos pés" (Mt 10), ecoando então as palavras sempre citadas de São Paulo, em todos os textos e postilas destes mestres peninsulares: "Porventura compete-me julgar os que estão de fora?" (1Cor 5).

Não estávamos, portanto, num contexto de puro relativismo, mas de prévia opção pela verdade e consequente formulação de uma hierarquia de valores, mas por isso mesmo se dignifica e valoriza o esforço destes homens para viverem a sua verdade sem procurarem vergar os outros, desrespeitando a liberdade e dignidade que essencialmente definia cada homem, queridas e conferidas por Deus, no momento da criação. Era essa a primeira condição da justiça e da paz que sobre ela se ergueria.

Vale então a pena terminar estas breves linhas com a pergunta colocada aos seus alunos por Domingo de Soto, na Universidade de Salamanca, em 1535, perante os relatos de ocupação do Novo Mundo pela força das armas "Portanto, com que direito retemos o império ultramarino recentemente descoberto? Na verdade não sei." 28 ${ }^{28}$ SOTO, Domingo de. Relectio de dominio, Salmanticae, 1535, p. 34, tradução deste excerto
de Pedro Calafate. 